American Journal of Environmental Sciences 7 (5): 441-447, 2011

ISSN 1553-345X

(C) 2011 Science Publications

\title{
Active Faulting and Quaternary Landforms Deformation Related to the Nain Fault
}

\author{
Abolghasem Gourabi and Mojtaba Yamani \\ Department of Physical Geography, Faculty of Geography, \\ University of Tehran, Tehran, Iran
}

\begin{abstract}
Problem statement: Landforms developed across terrain defining boundary the Nain fault have imprints of recent tectonic activity in the west region of Central Iran. Depositional landforms such as alluvial fans bear signatures of later phases of tectonic activity in the form of faulting of alluvial fan deposits and development of fault traces and scarps within $100 \mathrm{~km}$ long and a NW-SE-trending zone, 1000-2000 m wide. Approach: We are addressing the neotectonic landforms based on detailed field work carried out in the Nain exposed active fault segments which brought forward some outstanding morph tectonic evidence of quaternary tectonically activities. Tectonic geomorphology applied to the Nain fault suggests recent subsurface activity along the Nain fault and an interconnecting faulting network of roughly NW-SE-trending, right-lateral, strike-slip segments and mostly NW-SE-oriented, transtensional to normal faults. Results: Evidence for recent activity is provided by faulted PleistoceneHolocene deposits, fresh scarps in Late Quaternary deposits, 8-15 m lateral offsets locally affecting the drainage pattern of the area, ground creeping, aligning of series of spring faults, deflected streams and fault trace over recent alluvial fans. The existences of strike-slip faults system in the Nain area can be implications for seismic hazard. Conclusion: Motion along these structures suggests, in fact, that cumulative displacements include normal, transtensional and strike-slip components. Based on all evidence of active tectonics, earthquake risk and occurrence area is significant.
\end{abstract}

Key words: Quaternary landforms, Central Iran, nain fault, active faulting

\section{INTRODUCTION}

The Arabia-Eurasia collision deforms an area of $\sim 3,000,000 \mathrm{~km}^{2}$ of continental crust, making it one of the largest regions of convergent deformation on Earth (Allen et al., 2004; Al-Zoubi, 2005). Iran is one of the most seismically active regions along the Alpine Himalayan belts, with numerous destructive earthquakes recorded both historically and instrumentally (Fattahi et al., 2010) Fig. 1. In contrast to other parts of the Alpine-Himalayan system, in which active deformation is spread across regions several thousand kilometers wide, nearly all the convergence is accommodated in a relatively small area (herein Central Iran) defined by the political borders of Iran Fig. 1 and provides a compact region for the study of active tectonic (Walker et al., 2010). The Central Iranian Terrane consists, from east to west, of three major crustal domains: the Lut Block, Tabas Block and Yazd Block separated by a series of intersecting regionalscale faults (Fig. 1). Iran major strike-slip faults of central Iran that have been assessed for paleoseismicity are typically associated with block boundaries, such as the Doruneh and the Dasht-e Bayaz faults (North of central Iran); the Nehbandan fault (East of Lut); the Bam-Gowk-Kuh Banan system faults, the Mahan-Jorjafk system faults and the Rafsanjan-Rayen system faults (East of Kerman); the Nain, the Dehshir and the shahr-e-Babak fault systems (South-West of Central Iran) and the Nay band fault (West of Lut).

Other active strike-slip faults are located within the minor blocks and define lesser faults Fig. 1. Active tectonic movements in the Central Iran mainly along the main faults and main boundary faults are very common (Berberian and Yeats, 2001; Moghimi, 2009). In the Central Iran region, the accumulated strain energy of active tectonics is linked to deformation of the detachment surfaces (Berberian, 2005). Almost the entire faults of the Central Iran are seismically very active. The geomorphic development in this region is a result of the interaction between climate and tectonics (Gourabi and Nouhegar, 2007). As the active deformation in central Iran appears to be concentrated along the fault segments, this study focuses on the geomorphic development of the Nain fault in response to the neotectonic movements. 


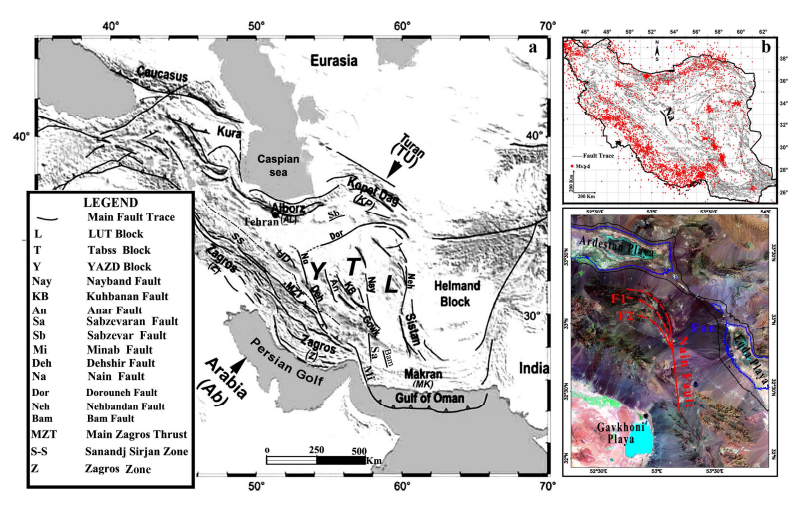

Fig. 1: (a) Simplified topographic (derivative from SRTM90) and tectonic map of Iran and adjacent regions. The LUT block is marked by "L", the Alborz by "AL", the KoPeh Dagh by "KP" and the Holmand block by " $H$ ". The Nain fault marked by "Na" (b) Instrumentally recorded earthquake epicentres in Iran (Yamani et al., 2010) (c) ETM+ imagary shows location of the Nain fault and Nain Alluvial fan

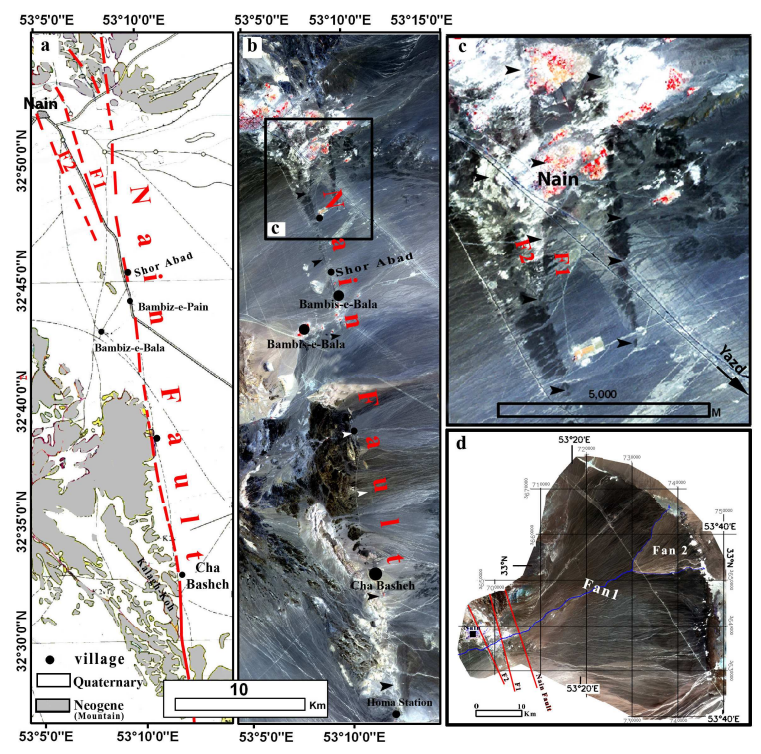

Fig. 2: (a) Geology map of the Nain fault, (b) ETM satellite image, (c) enlarge of "c" in b and (d) the Nain alluvial fan (ASTER image).

Study area: The Nain fault regarded as a strike-slip fault; it is more likely a normal fault which moves quietly. Strike-slip faults would have been playing a critical role in the development of pale seismology in Iran for several reasons. First, strike-slip faults are often the longest faults on continental landmasses and typically have conspicuous geomorphic expression. Second, many of these faults have long records of seismicity because they pass through populated continental regions and have experienced surface ruptures during large and great historical earthquakes.

Third, because coseismic deformation along strikeslip faults is horizontal, subsequent earthquakes do not deeply bury, or expose to erosion, traces of earlier events (Yamani et al., 2010; Azad et al., 2011; Bachmanov et al., 2004; Walker et al., 2010; Weldon et al., 1996).

The Nain fault is the westernmost strike-slip fault of N-striking dextral faults that slice Central and western Iran (Yamani et al., 2010). This right-lateral fault is around $100 \mathrm{~km}$ long and trends N-S between $32^{\circ} .20^{\prime} \mathrm{N}$ and $33^{\circ} .140^{\prime} \mathrm{N}$. The $100 \mathrm{~km}$ long the Nain fault of the runs from Ardestan Playa in the north to Gavkhoni playa in the south Fig. 1-2. The analytical data collected from previous researches suggest initial displacement along the Nain fault to $570 \mathrm{Ma}$, until at the present time (Yamani et al., 2010). These data indicate that the Nain fault in the western central Iran is an ancient fault. OSL date of the surface sediments obtained from central Iran and near the Nain fault suggests that theses sediments are settled from 2.0 0.2 kyr ago to recent (Fattahi et al., 2006; 2010). Although the geomorphologic evidences along the Nain fault are in agreement with an active fault, however, on earthquake map, the Nain fault reveal to be aseismic area with negligible earthquakes Fig. $1 \mathrm{~b}$.

Based on remote sensing and fieldworks observations and contrasting to the other researches in central Iran (Ritz et al., 2006; Talebian and Jackson, 2002; McEvilly and Niazi, 1975; Meyer et al., 2006; Tchalenko et al., 1973; Walker et al., 2010) the Nain fault has been active since at least early Holocene time. Active strike-slip Nain faulting produces an assemblage of stratigraphic and geomorphic markers including linear valleys, offset or deflected streams, shutter ridges, sag ponds, scarps and fault traces. Historically, geomorphic studies have tended to yield the size of pale earthquakes and stratigraphic studies the timing of pale earthquakes (Bull, 2007). The regularity and linear of the fault trace is the evidence of a highly inclined fault plane ( vertically). Apart from the recent findings, the Nain fault with its subsidiaries, in some localities particularly in south and north parts, behaves as a normal fault as field evidence suggests. Through this study we have tried to relate our field investigations with the abovementioned study. We have tried to bring forward some outstanding landscape features formed as a result of active tectonics in the region. 


\section{MATERIALS AND METHODS}

This study discusses the late Quaternary tectonic movement of the Nain fault based on detailed geomorphologic mapping. We first scrutinized the Nain fault on the satellite imageries (Landsat, Aster and QuakBird), topographic features and modeling's extracted from SRTM and fieldworks and then selected three regions in the study area that exhibited distinct tectonic deformation for estimating the quaternary deformation. Geomorphic surfaces along the Nain fault including the fluvial surfaces, fault traces, alluvial fans, linear valleys, offset or deflected drainages, sag ponds and some deformed surfaces were mapped using topographic maps, visual interpretation of air-photos and satellite images, field observations and GPS surveying. Topographic maps have a scale of 1:50,000 and 1:25,000. They were constructed by the NCC (National Cartographic Center of Iran). The air-photos have scales of between ca. 1:20,000 and 1:50,000 and were also provided by the NCC and NGO (National Geographical Organization). We identified small-scale landforms along the faults indicative of tectonic movement, such as offset or deflected drainages, sag ponds and fault scarps (Keller and Pinter, 2002; McCalpin, 2009). Large-scale tectonic landforms including alluvial fans were also identified. The offset streams were used to measure the amount of strike-slip along the Nain fault at various locations. We also investigated the material forming geomorphic surfaces including tectonically deformed features such as the dried bed of sag ponds. We used excavated trench in study area (Water pipeline trenches dug between Isfahan and Yazd) to observe the Nain fault plan to identify faulting geometry. The results of dating and inferred surface ages from previous were collated with the measured amount of tectonic deformation at each location to estimate the rate of deformation.

\section{RESULTS AND DISCUSSION}

Quaternary Landforms along the Nain Fault: In the study area, various geomorphic domains have developed. The foothill zone of area is occupied by different fans and towards the flat surfaces developed the playas. Towards the north, study area is exposed and abruptly uplifted along the Nain fault. The frontal part of the topographic area especially along the Nain fault is covered with piedmont gravels (e.g., Chah Basheh to Bambis-e-Pain, Fig. 2b. The subsidiary faults of the Nain fault are stretched in the western limit of the main Nain fault trace toward the northern parts. Many drainages flow transverse to the Nain fault and display vertical incision indicating uplift of the channel floor.
Some drainages flows parallel to the Nain fault zone (along fault trace). In the north region of the Nain fault (Nain area) and from east to west, one to four eastward dipping surface breaking normal faults have been observed Fig. 2 and 5. Neotectonic movement along these faults and southern part of the Nain fault has resulted in the formation of several lineation's Fig. 2. Indeed, these lineations are linear patterns observed on imagery that represent active faults. The fractures may be either joints or faults. Each lineation typically represents a fracture zone. Lineation's include; straight drainage segments, linear alignments of natural vegetation (Alignments of villages along the Nain fault, Fig. 2, sag ponds Fig. 5 and 5, scarps and fault traces Fig. 2 and 3, linear springs (Herein villages; Fig. 2b, aligned topographic features and linear changes in image tone or texture in field or satellite imageries Fig. 2b-c.

A number of alluvial fans are seen along the eastern of the Nain fault. These fans almost have been extended on the footwall of the Nain fault system. These have coalesced to form a geomorphic surface termed as "bajada" adjointed fans). The Nain alluvial fan is one of the most alluvial fans in central Iran. This fan has an area of ca. $1557 \mathrm{~km} 2$ and a steep gradient of $1.35 \%$ Fig. $1 \mathrm{c}$ and $2 \mathrm{~d}$. The longer length of the Nain fan surface is $48 \mathrm{~km}$ and its width is $52 \mathrm{~km}$. Normal faulting of the Nain fault system has resulted in the uplift of the hanging wall and resulted in faulting of the Nain alluvial fan at Nain area Fig. 2d.

The Nain fault trace cuts $\sim 25 \mathrm{~km}$ the Nain alluvial fan along the fault zone. The constituting materials of the fan (boulders, gravels, rock fragments and sand) are derived from steep slopes of the Nain fault hanging wall. The source basin has an area of ca. $1550 \mathrm{~km}^{2}$ and the relative height is ca. $2100 \mathrm{~m}$. In the footwall of the Nain fault area the Nain river Fig. 2d has incised deeply into the ancient fan to form a V-shaped valley.

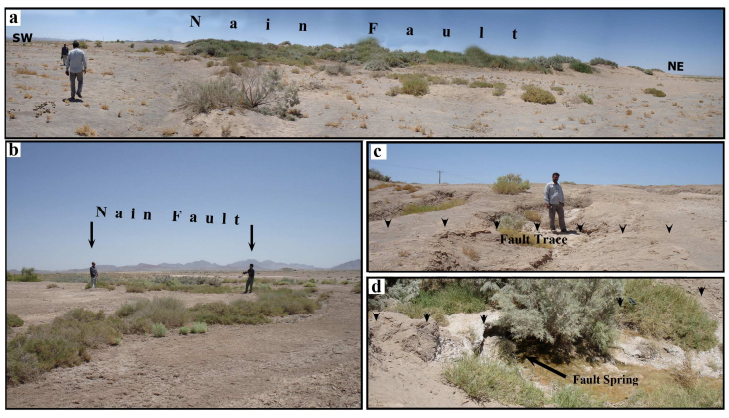

Fig. 3: Evidence of active faulting along the Nain fault near Homa railway station; (a) aligned vegetation along the Nain fault, (b) Deflated drainage across the Nain fault, Fault trace of the Nain fault and (d) Fault spring along the Nain fault 


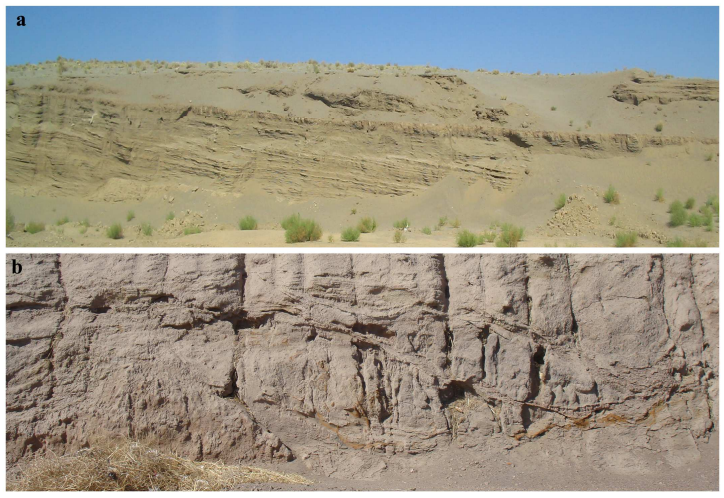

Fig. 4: Deformation of quaternary landform along Nain fault near villages of; (a) Shor Abad, (b) Bafran

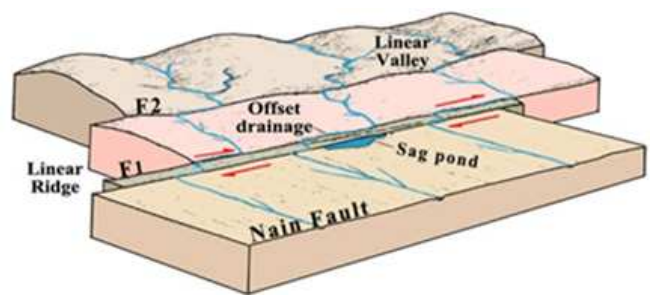

(a)

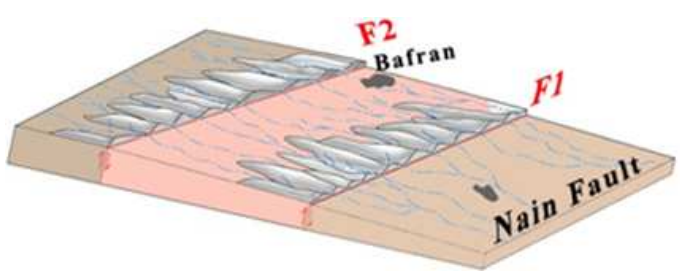

(b)

Fig. 5: Formation mechanism of quaternary landforms by the Nain active fault systems in the Nain area

The active tectonic movements in the Nain alluvial fan have developed fault scarps of the Nain fault which is clearly visible on the fan surface on imageries Fig. 2. The drainages that have laid the fan materials and flowing across the Nain fault has been deflected southward due to the Nain strike-slip faulting. Drainages flowing across the Nain fault are characterized by a series of knick points in the form of cascading fault scarps.

In the following, we describe the characteristics of the fault related landforms in the selected areas, from south to north.

Active faulting and displacement of landforms: There seems to be a relation between the formation of the recent morph tectonic features along the Nain fault and associated NW-SE striking faults system faulting.
The shematic model clearly shows the differential movements on active the Nain fault and NW-SE trending fault Fig. 5. Fault scarps have been observed towards the NNE of the Nain fault in Nain region. Two minor fault strands F1 and F2 show normal faulting towards the northwest. The F1 and the main Nain faults meet at an acute angletowar south. Toward north, the F2 diverges from the F1. This segmentation continues repeatedly to north and many minor faults appear as drainage parallel pattern. The Nain fault displaced the drainage by $11 \mathrm{~m}$ near Shor Abad Fig. 2a. During the propagation of the Nain fault and its subsidiaries (F1, F2), due to compressive tectonic movement, the alluvial sediments have been displaced over the recent surface. The geomorphic markers relationship and pattern of displacement suggest that large tectonic events have been continued in the region after the deposition of the Nain alluvial fan.

In the south of the Nain fault region (near Homa railway station, Fig. 2, the Nain faulting has displaced the drainage about $9 \mathrm{~m}$ along a sag pond science Quaternary Fig. 3b.

Active faulting and folding of quaternary sediments: In the south of the Nain fault (near Shor Abad village) the eolian and alluvium strata beside the Nain fault plan dip $30-45^{\circ}$ towards the north whereas these layers settled horizontally originally Fig. 4a. Steeping of strata in the Nain fault might be due to continuous progressive movement of the Nain fault blocks towards north. In this area, the hanging wall of initially existed normal plane slided northward and gave rise normal sense of dip-slip movement, resulted in offsetting of the order of $\sim 10 \mathrm{~m}$ along the strike length. In addition, to the north and near the Bafran village, Quaternary sediments are folded on each side of the Nain fault Fig. $4 \mathrm{~b}$.

Active faulting and creation of sag ponds and fault scarps along the Nain fault zone: One of the tectonically induced witnesses along the Nain fault is the sag ponds. A significant development along the 100 $\mathrm{km}$ normal of the Nain fault has been the pending of the streams due to fault movement. Several pieces of evidence suggest that stream impoundment in Homa railway Station area has taken place due to the reactivation of the Nain fault. This phenomenon resulted in the uplift of the hanging-wall coincident footwall depression of the Nain fault resulting in the formation of the small playa. Therefore, the study of sag pond is important to understand the tectonic history of the region. Furthermore, between main and minor of the Nain faults, near Bafran area of Nain region three tectonically induced sag ponds are found Fig. 5. 
Am. J. Environ. Sci., 7 (5): 441-447, 2011

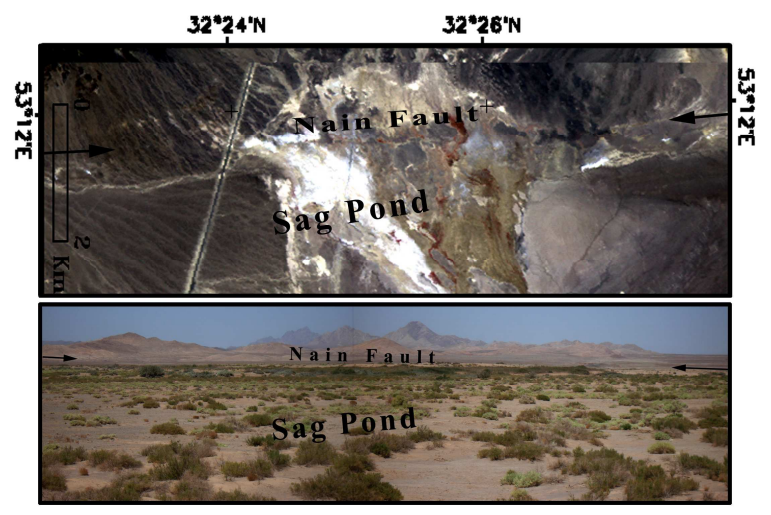

Fig. 6: Active faulting and creation of sag pond along the Nain fault

Sag ponds depressions are aligned in the same northern most major and minor faults and remain dry in most part of the year while water briefly accumulates during the winter precipitations Fig. 6. Homa railway station, Chah Basheh and Cheshmeh-Gazi springs were formed due to movement along the Nain faults. All subsidiaries of the Nain faults have created many fault scarps. We measured some fault scarps in fieldworks. Faults scarps height between 3-10 m changes.

Mass movement along the Nain fault: Towards north and south of the Nain fault, massive active rock falls are taking place. Vertical displacement of late Pleistocene to early Holocene strath terraces and truncation of drainages have been observed between the Chah-Basheh to Bambis-e-Pain Fig. 2. Various modes of slope failures are common along the Nain fault at mountainside area. The occurrence of mass movement depends on the interaction of various factors. The kingpin of mass movement occurrence in this study area is due to the neotectonic activity going on along the faults zone. These occur in various extents roughly $30 \mathrm{~km}$ from south in the Nain to southeast, west of Kalagh-Koh in the Chah-Basheh region Fig. 2 including displacement of the slope by falls, toppling, slumps and debris flows as a function of gravity. The eastern hills of Kalagh-Koh are susceptible to various types of mass movement.

Exposed surfaces of debris flows suggest that these take place as a result of the intersection of multiple joint planes in the vicinity of the Nain fault zone. Neotectonic movements along the Nain fault have not only made the slopes steeper but have also subjected the rocks in the fault zone to brittle deformation.

\section{CONCLUSION}

This study focuses on the geomorphic development of Nain area in response to the neotectonic movements along the Nain fault systems. Intense tectonic activity has led to the development of some spectacular landscape features which have been brought forward in this study. The study has shown that the neotectonic movements in Nain area occur along the branches of the Nain faults due to sequence deformation. The date of fault obtained from neotectonics evidence indicates its reactivation quaternary. Roughly $3-10 \mathrm{~m}$ vertical displacement of the Nain fault blocks has been observed along the Nain fault. Most of the displacement in Nain region has been recorded in the mid-part of the Nain fault and is about $11 \mathrm{~m}$. The Qanat wells are dug in alluvial sediment of the Bambis-e-Pain region suggests that the vertical separation of two blocks of the Nain fault is $\sim 3-5 \mathrm{~m}$. It has been suggested that Nain region is deforming by a tectonic forces now.

This study several evidence (sag ponds, fault traces, deflected stream, uplifted terrain, faulted alluvial fan and fault scarps) were brought forward which suggest that the Nain fault has been behaving as a the active fault in Nain region. A large alluvial fan was observed in the catchment of Nain river. Displacement of the Nain area resulted in the uplift and truncation of alluvial strath along all drainages. We have tried to develop a conceptual model for the evolution of the alluvial fans in the Nain fault zone Fig. 5. The fans were formed as a result of faulting and rapid uplift of the hanging wall along the Nain fault zone during the first phase. The initial uplift of west area took place along the Nain fault. The rapid uplift in the region caused erosion in the uplifted region and deposition in the footwall region of the Nain fault at a very fast rate Fig. 1 and 2. In the later phase of tectonic movement fault scarps were formed Fig. 3d. Later the fan surface was dissected during the second phase of tectonic movement.

The active deformation along the Nain fault has led to the splitting of a sag pond along its splays to give rise to a peculiar playa (e.g., in Homa railway station area. Fig. 4 and 5). A hypothetical model has been proposed to explain the origin of these sag ponds Fig. 4. A hypothetical model has been proposed to explain the evolution of these depressions. The model suggests that these depressions may have been connected in the quaternary. Movements along the branches of the Nain fault have resulted in opening of these depressions along the detachment zone of the Nain fault. Consequently, the depressions were split into two along the branches and the lower sediments got sink by 5-10 $\mathrm{m}$ in the region Fig. 6. Towards the upper catchments in Nain, several depressions were observed along the trace of the Nain fault. Therefore, these depressions were formed in the syn-tectonic movements along the Nain fault. The tectonic model suggests that during the first 
phase of tectonic movements along the Nain fault, the footwall subsidence over the quaternary. The normal faulting phenomenon of the Nain fault is responsible for uplift and blocking the mouth of the stream to form playa Fig. 5a. Drainages flowing across the Nain fault have deflected southward leaving behind palaeochannels. Drainages flowing across the Nain fault are also characterized by a series of knick points in the form of cascading scarps. The intense tectonic activity along the Nain fault has made the region susceptible to mass movements (e.g., rockfalls). The rocks are defined by brittle deformation with multiple joint sets creating an ideal state for wedge failures particularly during years.

\section{ACKNOWLEDGEMENT}

We are grateful to the Faculty of Geography, University of Tehran, for a grant towards the costs of field works.

\section{REFRENCES}

Allen, M., J. Jackson and R. Walker, 2004. Late Cenozoic reorganization of the Arabia-Eurasia collision and the comparison of short-term and long-term deformation rates. Tectonics, 23: 16-16. DOI: $10.1029 / 2003$ TC001530

Al-Zoubi, A.S., 2005. The $11^{\text {th }}$ February, 2004 Earthquake of The Dead Sea, Jordan. Am. J. Environ. Sci., 1: 142-148. DOI: 10.3844/ajessp.2005.142.148

Azad, S.S., J.F. Ritz and M.R. Abbassi, 2011. Leftlateral active deformation along the Mosha-North Tehran fault system (Iran): Morphotectonics and paleoseismological investigations. Tectonophysics, 497: 1-14. DOI: 10.1016/j.tecto.2010.09.013

Bachmanov, D.M., V.G. Trifonov, K.T. Hessami, A.I. Kozhurin and T.P. Ivanova et al., 2004. Active faults in the Zagros and central Iran. Tectonophysics, 380: 221-241. DOI: 10.1016/j.tecto.2003.09.021

Berberian, M. and R.S. Yeats, 2001. Contribution of archaeological data to studies of earthquake history in the Iranian Plateau. J. Structural Geol., 23: 563584. DOI: 10.1016/S0191-8141(00)00115-2

Berberian, M., 2005. The 2003 Bam urban earthquake: a predictable seismotectonic pattern along the Western margin of the rigid lut block, Southeast Iran. Earthquake Spectra, 21: S35-S99. DOI: 10.1193/1.2127909

Bull, W.B., 2007. Tectonic Geomorphology of Mountains: A New Approach to Paleoseismology. 1st Edn., John Wiley and Sons, Malden, MA., ISBN: 1405154799 , pp: 316.
Fattahi, M., R. Walker, J. Hollingsworth, A. Bahroudi and H. Nazari et al., 2006. Holocene slip-rate on the Sabzevar thrust fault, NE Iran, determined using optically stimulated luminescence (OSL). Earth Planetary Sci. Lett., 245: 673-684. DOI: 10.1016/j.epsl.2006.03.027

Fattahi, M., H. Nazari, M.D. Bateman, B. Meyer and M. Sebrier et al., 2010. Refining the OSL age of the last earthquake on the Dheshir fault, Central Iran. Quaternary Geochronol., 5: 286-292. DOI: 10.1016/j.quageo.2009.04.005

Gourabi, A.A.G. and A. Nouhegar, 2007. Geomorphic indices of active tectonics in darakeh basin. Geographical Res. Q., 39: 177-196.

Keller, E.A. and N. Pinter, 2002. Active Tectonics: Earthquakes, Uplift and Landscape. 2nd Edn., Prentice Hall, Upper Saddle River, NJ., ISBN: 0130882305, pp: 362.

McCalpin, J., 2009. Paleoseismology. 2nd Edn., Academic Press, London, ISBN 0123735769, pp: 613 .

McEvilly, T.V. and M. Niazi, 1975. Post-earthquake observations at Dasht-e Bayaz, Iran. Tectonophysics, 26: 267-279 DOI: 10.1016/00401951(75)90094-3

Meyer, B., F. Mouthereau, O. Lacombe and P. Agard, 2006. Evidence of quaternary activity along the deshir fault: Implication for the tertiary tectonics of Central Iran. Geophys. J. Int., 164: 192-201. DOI: 10.1111/j.1365-246X.2005.02784.x

Moghimi, E., 2009. comparative study of changing drainage basin system with tectonic forms, case study: Lut block, Iran. Am. J. Applied Sci., 6: 1270-1276. DOI: 10.3844/ajassp.2009.1270.1276

Ritz, J.F., H. Nazari, A. Ghassemi, R. Salamati and A. Shafei et al., 2006. Active transtension inside central alborz: A new insight into northern Iransouthern Caspian geodynamics. Geology, 34: 477480. DOI: $10.1130 / \mathrm{G} 22319.1$

Talebian, M. and J. Jackson, 2002. Offset on the main recent fault of NW Iran and implications for the late Cenozoic tectonics of the Arabia-Eurasia collision zone. Geophysical J. Int., 150: 422-439. DOI: 10.1046/j.1365-246X.2002.01711.x

Tchalenko, J.S., M. Berberian and H. Behzadi, 1973. Geomorph 1c and seismic evidence for recent activity on the Doruneh Fault, Iran. Tectonophysics, 19: 333-341. DOI: 10.1016/00401951(73)90027-9

Walker, R.T., M. Talebian, S. Saiffori, R.A. Sloan and A. Rasheedi et al., 2010. Active faulting, earthquakes and restraining bend development near Kerman city in southeastern Iran. J. Structural Geol., 32: 1046-1060. DOI: 10.1016/j.jsg.2010.06.012 
Weldon, R.J., J.P. McCalpin and T.K. Rockwell, 1996. Chapter 6 Paleoseismology of strike-slip tectonic environments. Int. Geophy., 62: 271-329. DOI: 10.1016/S0074-6142(96)80073-8
Yamani, M., M.R. Ghasemi, S.K. Alavipanah, A.A.G. Gourabi, 2010. Morphotectonic Of dehshir area using geomorphometric techniques. Phys. Geography Res. Q. 